PROCEEDINGS

oF

\title{
The American Microscopical Society
}

\section{ADDRESS OF THE PRESIDENT.}

The Processes of Life Revealed by the Microscope; a Plea for Physiological Histology.

Simon Henry Gage, B. S., Ithaca, N. Y.

It is chafacteristic of the races of men that almost at the dawn of reflection the first question that presses for solution is this one of Life; life as manifested in men and in the animals and plants around them. What and whence is it and whither does it tend? Then the sky with its stars, the earth with its sunshine and storm, light and darkness, stand out like great mountain peaks demanding explanation. So in the life of every human being, repeating the history of his race, as the evolutionists are so fond of saying, the fundamental questions are first to obtrude themselves upon the growing intelligence. There is no waiting, no delay for trifling with the simpler problems, the most fundamental and most comprehensive come immediately to the fore and alone seem worthy of consideration. But as age advances most men learn to ignore the fundamental questions and to satisfy themselves with simpler and more secondary matters, as if the great realities were all understood or non-existent. No doubt to many a parent engaged in the affairs of society, politics, finance, science or art, the questions that their children put, like drawing aside a thick curtain, bring into view the fundamental questions, the great realities; and we know again that what is absorbing the power and attention of our mature intellect, what perhaps in pride we feel a mastery over, are only secondary matters after all, and to the great questions of our own 
youth, repeated with such earnestness by our children, we must confess with humility that we still have no certain answers. It behooves us then, if the main questions of philosophy and science cannot be answered at once, to attempt a more modest task, and by studying the individual factors of the problem to hope ultimately to put these together and thus gain some just comprehension of the entire problem.

This address is, therefore, to deal, not with life itself, but with some of the processes or phenomena which accompany its manifestations. . But it is practically impossible to do fruitful work according to the Baconian guide of piling observation on observation. This is very liable to be a dead mass, devoid of the breath of life. It is a well-known fact that the author of the Novum Organon, the key which Bacon supposed would serve as the open-sesame of all difficulties and yield certain knowledge, this potent key did not unlock many of the mysteries of science for its inventor. Every truly scientific man since the world began has recognized the necessity of accurate observation, and no scientific principle has ever yet been discovered simply by speculation; but every one who has really unlocked any of the mysteries of nature, has inspired, made alive his observations by the imagination; he has, as Tyndall so well put it, made a scientific use of the imagination and created for himself what is known as the "working hypothesis." It must be confessed that for some investigators the "hypothesis" becomes so dear that if the facts of nature do not conform to the hypothesis, "so much the worse for the facts." But for the truly scientific man, the hypothesis is destined solely to enable him to get the facts of nature in some definite order, an order which shall make apparent their connection with the great order and harmony which is believed to be present in the universe.

If the working hypothesis fails in any essential particular he is ready to modify or discard it. For the truly inspired investigator, one undoubted fact weighs more in the balance than a thousand theories.

At the very threshold of any working hypothesis for the Biol- 
ogist, this question as to the nature of the energy we call life must be considered. The great problem must receive some kind of a hypothetical solution. What is its relation to the energies of light, heat, electricity, chemism and the other forms discussed by the physicist? Are its complex manifestations due only to these, or does it have a character and individuality of its own? If we accept the ordinarily received view of the evolution of our solar system, the original fiery nebula in which heat reigned supreme, slowly dissipated part of its heat, and hurled into space the planets, themselves flaming vapors, only the protons of the solid planets. As the heat became further dissipated there appeared in the cooling mass manifestations of chemical attraction, compounds, at first gases, then liquids, and finally, on the cooling planets, solids appeared. Lastly upon our own planet, the earth, when the solid crust was formed and the temperature had fallen below the boiling point of water, the seas were formed and then Life appeared. Who could see, in the incandescent nebula, the liquids and solids of our planet and the play upon them of chemism, of light, heat, electricity, cohesion, tension, and the other manifestations so familiar to all? And yet, who is there that for a moment believes that aught of matter or energy was created in the different stages of the evolution? They appeared or were manifested just as soon as the conditions made it possible. So it seems to me that the energy called Life manifested itself upon this planet when the conditions made it possible, and it will cease to manifest itself just as soon as the conditions become sufficiently unfavorable. It was the last of the forms of energy to appear upon this planet and it will be the first to disappear.

In brief, it seems to me that the present state of physical and physiological knowledge warrants the assumption, the working hypothesis, that Life is a form of energy different from those considered in the domain of physics and chemistry. This form of energy is the last to appear, last because more conditions were necessary for its manifestations. It, like the other forms of energy, requires a material vehicle through which to act, but the results produced by it are vastly more complex. Like the other ener- 
gies of nature it does not act alone. It acts with the energies of the physicist, but as the master; and under its influence the manifestations pass infinitely beyond the point where for the ordinary energies of nature it is written "thus far and no farther."

It can be stated without fear of refutation that every physiological investigation shows with accumulating emphasis that the manifestations of living matter are not explicable with only the forces of dead matter, and the more profound the knowledge of the investigator the more certain is the testimony that the Life energy is not a mere name. And, strange to say, the physicist and the chemist are most emphatic in declaring that life is an energy outside their domain.

The statements of a chemist, a physicist and a biologist are added. From the character and attainments of these men, their testimony, given after years of the most earnest investigation and reflection, is worthy of consideration:-

When Liebig was asked if he believed that a leaf or a flower could be formed or could grow by chemical forces, he answered: "I would more readily believe that a book on chemistry or on botany could grow out of dead matter by chemical processes."

"The influence of animal or vegetable life on matter is infinitely beyond the range of any scientific inquiry hitherto entered on. Its power of directing the motions of moving particles, in the demonstrated daily miracle of our human free will, and in the growth of generation after generation of plants from a single seed, are infinitely different from any possible result of the fortuitous concourse of atoms; and the fortuitous concourse of atoms is the sole foundation in philosophy on which can be founded the doctrine that it is impossible to derive mechanical effect from heat otherwise than by taking heat from a body at a higher temperature, converting at most a definite proportion of it into mechanical effect, and giving out the whole residue to matter at a lower temperature." - Sir William Thomson (Lord Kelvin).

"The anagenetic [vital] energy transforms the face of nature by its power of assimilating and recompounding inorganic matter, and by its capacity for multiplying its individuals. In spite of 
the mechanical destructibility of its physical basis (protoplasm) and the ease with which its mechanisms are destroyed, it successfully resists, controls and remodels the catagenetic [physical an chemical] energies for its purpose."-Cope.

What, then, are the manifestations of the life energy? and what are the processes which are discernible? All of us in whatever walk of life will recognize the saying of Gould:- "Now, when one looks about him the plainest, largest fact he sees is that of the distinction between living and lifeless things."

As life goes on and works with power where the unaided eye fails to detect it, the microscope-marvelous product of the life energy in the brain of man, shows some of these hidden processes. It has done for the infinitely little on the earth what the telescope has done for the infinitely great in the sky.

Let us commence with the little and the simple. If a drop of water from an aquarium, stream or pool is put under the microscope many things appear. It is a little world that one looks into, and like the greater one that meets our eye on the streets, some things seem alive and some lifeless. As we look we shall probably find, as in the great world, that the most showy is liable in the end to be the least interesting. In the microscopic world there will probably appear one or more small rounded masses which are almost colorless. If one of these is watched, lo! it moves, not by walking or swimming, but by streaming itself in the direction. First a slender or blunt knob appears, then into it all of the rest of the mass moves, and thus it has changed its position. If the observation is continued this living speck, which is called an amøba, will be seen to approach some object and retreat, indeed, it comports itself as if sensitive, with likes and dislikes. If any object suitable for food is met in its wanderings the living substance flows around it, engulfs it and dissolves the nutrient portions and turns them into its own living substance; the lifeless has been rendered alive. If the eye follows the speck of living matter, the marvels do not cease. After it has grown to a certain size, as if by an invisible string, it constricts itself in the middle and finally cuts itself in two. The 
original amøba is no more, in its place there are two. Thus nearly at the bottom of the scale of life are manifested all of the fundamental features - the living substance moves itself, takes nourishment, digests it and changes non-living into living substance and increases in size ; it seems to feel and to avoid the disagreeable and choose the agreeable, and finally it performs the miracle of reproducing its kind, of giving out its life and substance to form other beings, its offspring.

Loculisuiton
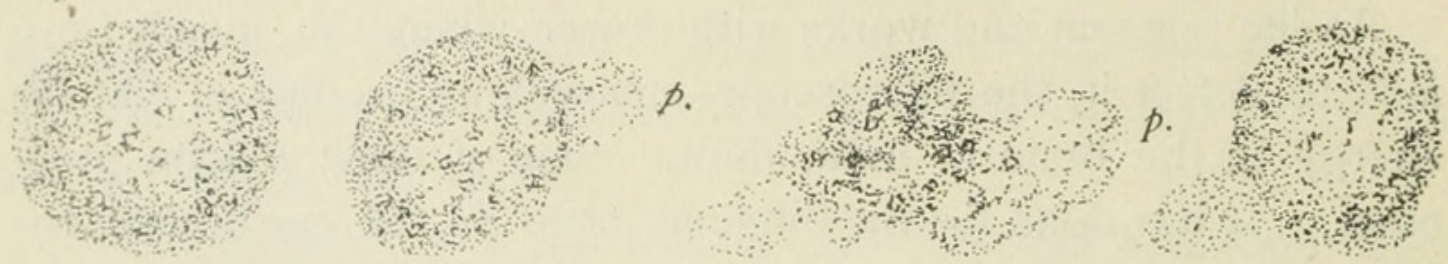

Choice
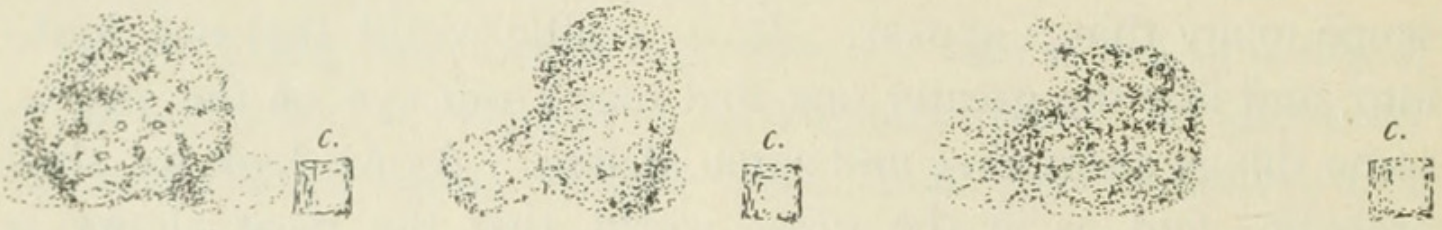

Nutrition
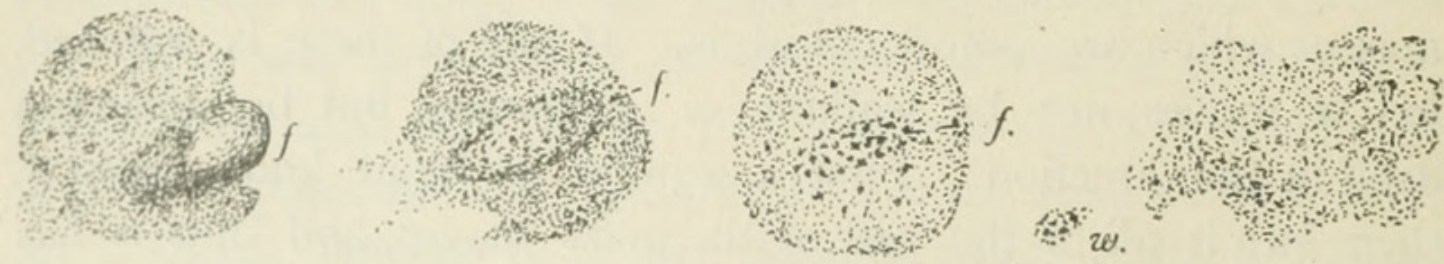

Reproduction
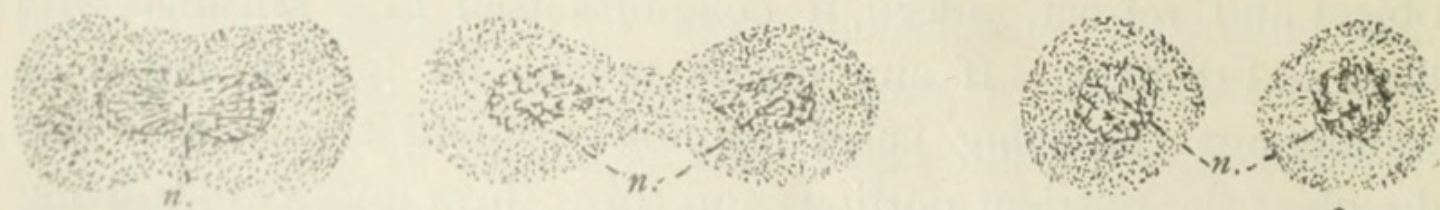

8 s.

Fig. 1. The Amoeba in its various phases of activity-Locomotion, Qhoice (irritability), Nutrition and Reproduction. The figures should be read from left to right, as with words in a book. (p.) Pseudopod; (c.) Crystal of substance distasteful to the amøba, hence the amoba withdraws from it ; $(f$.$) Food ingested and digested by the amoba for its nourishment.$ 
The indigestible matter $(w$.$) is extruded from the body and left behind.$ (n.) Nucleus. This is seen to divide first in reproduction, then the division of the cell body is completed, thus giving rise to two individuals.*

It is the belief of many biologists that the larger and complex forms even up to man himself may be considered an aggregation of structural elements originally more or less like the amœba just described; but instead of each member of the colony, each individual itself carrying on all the processes of life independently, as with the amœeba, there is a division of labor. Some move, some digest, some feel, think and choose, some give rise to new beings, all change lifeless matter into their own living substance.

The processes and phenomena by which a new individual is produced are included under the comprehensive term, Embryology.

All organisms great or small are but developments of minute germs budded off by the parent or parents, and the way in which these minute beginnings develop into perfect forms like their parents can only be followed by the aid of a microscope. Indeed in no field of biology has the microscope done such signal service in revealing the processes of life.

The method of the production of a new being with the amøba, as we have just seen, is for the parent to give itself entire to its offspring-the parent ceasing to be in producing its offspring. With some other lowly forms a part of the body of the parent buds out, grows and finally falls off as an independent organism, or remains connected with the parent to form a colony. In the vegetable world a familiar example of a colony is represented by the plant that the children call "Old Hen and Chickens."

In the higher animals, however, where specialization has been carried to its extreme limit, some myriads of cells forming the body are set apart to produce motion, others digest food, still others think, and feel, while comparatively few, the germ cells are destined for the continuation of the race. In the higher and highest forms especially, all observation goes to show that the life energy, not satisfied with the mere vitilization of matter and a

*The figures illustrating this address were drawn by Mrs. Gage. 
dead level of excellence, is aiming at perpetual ascent, greater mastery over matter and its physical forces. For the more certain attainment of this end, the production of offspring is no longer possible for one individual ; two wholly separate individuals must join, each contributing its share of the living matter which is to develop into a new being. In this way the accumulated acquirements of two are united with the consequent increase in the tendencies and impulses for modification, and nearly double the protection for the offspring. Thus, in striking contrast with the amœba, where the single parent gives all of itself to form offspring and in so doing disappears and loses its identity, in the higher forms, while two must unite to form the offspring, the parents remain and retain their individuality and the ability to produce still other offspring. The process by which this is accomplished may be traced step by step with the microscope. A germ cell of the father and one of the mother fuse together, and from this new procreative cell formed by the fusion of two with all their possibilities combined, the new individual arises. This certain knowledge is the result of the profound investigation of the last few years and shows the literalness of the scriptural statement, "they shall be one flesh."

After this fusion of the father and mother germ cells, the single cell thus formed, like the amœba, divides into two, and these into four and so on, but unlike the amœba all the cells remain together. Within this celular mass, as if by an unseen builder, the cells are deftly arranged in their place, some to form brain, some heart, some the digestive tract, others for movement; so that finally from the simple mass of cells, originally so alike, arises the complex organism, fish or bird, beast or man. How perfectly the word offspring describes the life process in the production of this new being! That the child should resemble both father and mother is thus made intelligible, for it is a part of both. Yes, further, it may resemble grandfather or great grandfather or mother, for truly it is a part of them, their life conserved and continued. There is no new life, it is only a continuation of the old: "Omne vizum ex vivo," all life from life. But 

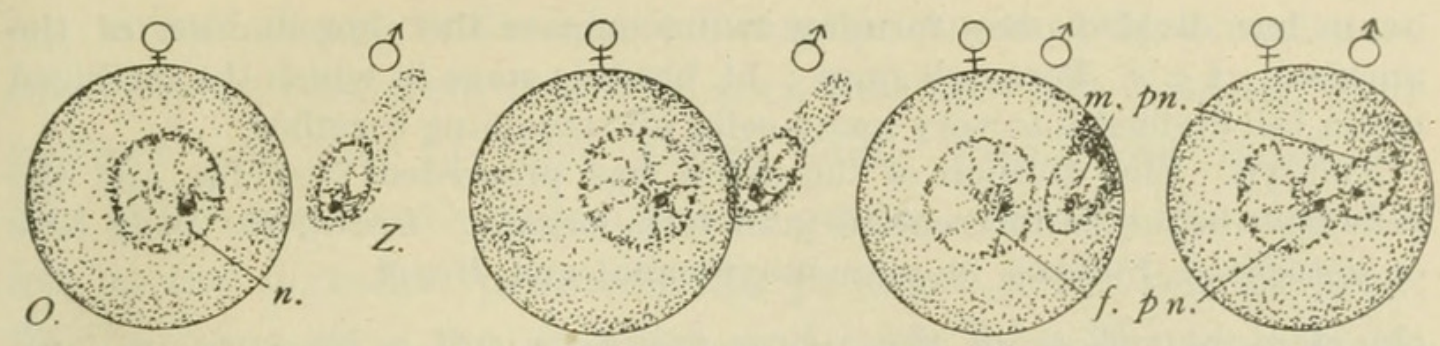

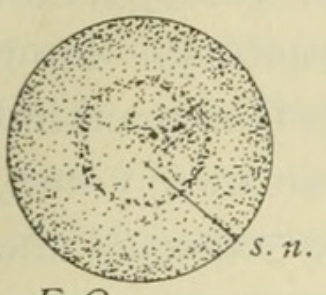

F. O.

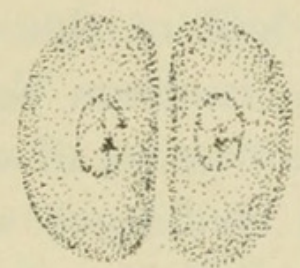

2. c. s.

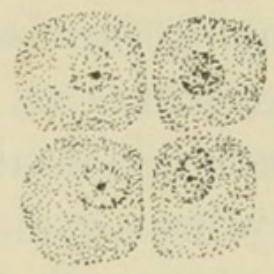

4. c.s.

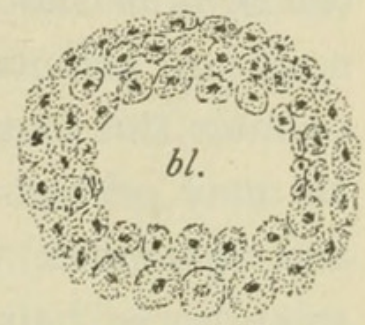

$\cos -2$

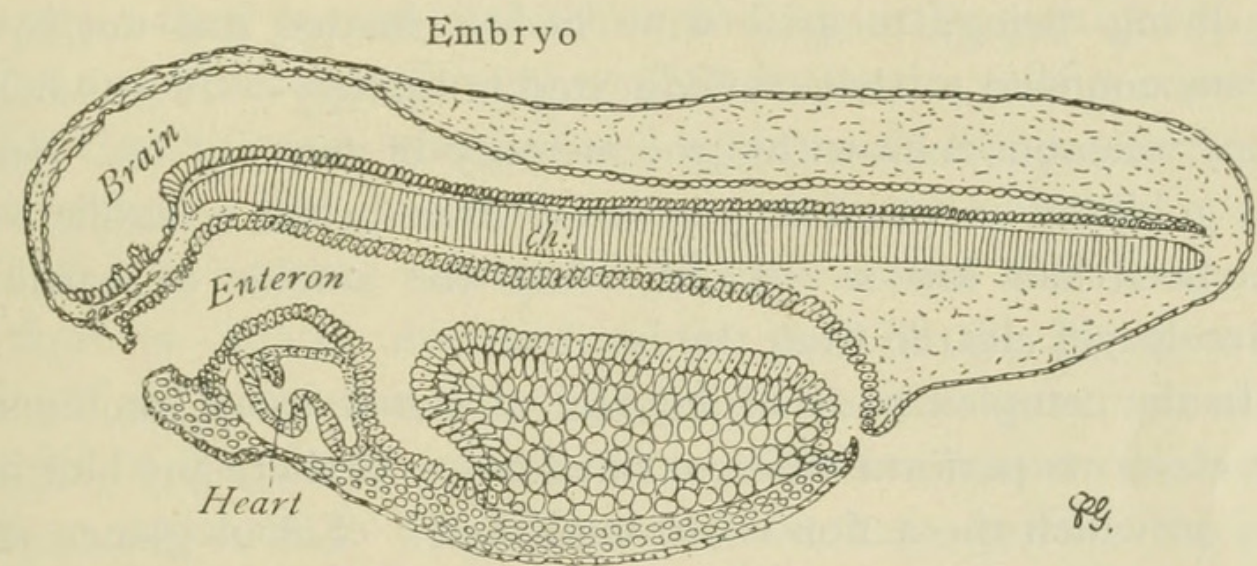

Fig. 2. Various phases in the reproduction of one of the higher animals In the upper series is shown the fusion of the father and mother germ cells, in the middle series appear some of the earlier phases of segmentation of the fertilized ovum. The lower figure (modified from Marshall) represents a medisection of an amphibian embryo sufficiently far advanced to show that the original cells into which the ovum divided, have differentiated and arranged themselves in such a manner as to form the beginnings or protons of the great systems of organs-Brain, Enteron and Heart.

$O$. Ovum, $(n)$ Nucleus of the ovum. of This sign indicates that the ovum is a mother or female germ-cell. $Z$. Zoösperm. of Sign indicating that the zoösperm is a father or male germ-cell. ( $f . p n$.) Female pronucleus. (m. $p n$.) Male pronucleus. These two pronuclei fuse and form the nucleus of the true reproductive cell, the fertilized ovum. In the two figures at the right both signs ( $\left.\begin{array}{l}f \\ o\end{array}\right)$ are used to indicate that both germ cells are represented in each figure. $F$. $O$. Fertilized Ovum. That is the true reproductive cell composed of a father or male, and a mother or female germcell fused. The steps of the fusion are shown in the upper series.

$s$. $n$. Segmentation nucleus. $2 c . s$. Two-cell stage, that is the fertilized 
ovum has divided once forming two (compare the reproduction of the amœba). 4 c. $s$. Four-cell stage ; bl. blastula stage in which the fertilized ovum has divided into very many cells, all remaining together.

Embryo. The division of the ovum has proceeded very far, and the cells have begun to differentiate and form organs. Brain, ch. Body axis or notochord, Enteron or alimentary canal and Heart.

the demonstration of this prime fact required a microscope, and it is an achievement of the last half of this century. How counter this statement still is to the common belief of mankind we may perhaps better appreciate if we recall our own youth, and remember with what absolute confidence we expected the stray horse hairs we had collected and placed in water to turn into living snakes.* The belief that it is an every-day occurrence for living beings to arise from lifeless matter was not by any means confined to those uneducated in biology. It was held by many scientific men within the memory of most of us. Indeed this goblin of spontaneous generation, even for the scientific world, has been laid low so recently that the smoke of battle has scarcely yet cleared from the horizon.

In the complex body of animals, as stated above, the constituent elements perform different functions. Is there any hint of the way in which the action is accomplished? Let us glance at two systems, the nervous and the glandular,widely different in structure and function. All know how constantly the glands are called into requisition, the salivary glands for saliva, those of the stomach and the pancreas for their digestive juices, etc. If we take now the pancreas as an example, and that of a living, fast-

*Reference is here made to the nematoid worm Gordius. This worm lives a part of its life as a parasite in the larvæ of aquatic insects and in some fish. In the adult free condition it differs markedly from the larval, parasitic stage, and is very slender and much elongated, often reaching a length of 20 to 30 centimeters ( 8 to 10 inches), and has the general appearance of a coarse hair like that from the tail of a horse. It lives in water and in wet places and frequently appears in horse troughs and the wet places where the trough overflows. From the hair-like appearance it was and still is believed that a hair from the horse's tail or mane had directly transformed into a living creature. By many persons it is called a hair-snake, by others a hair-worm. Often one or several become tangled in an almost inextricable knot, whence the name from the famous "Gordian Knot." 
ing animal is put under the microscope so that its constituent cells can be observed, it will be seen that they are clouded, their outlines and that of their nuclei being vague and indistinct. The cell is apparently full of coarse grains. If now the animal is fed, as the digestion proceeds the pancreas pours out its juice. At the same time the granules, and with them the cloudiness, gradually disappear, the cells become clear and both they and their nuclei are sharply outlined. That is, the substance which is to form the pancreatic juice is stored in the cells in the form of granules during the periods of rest, and held until the digestive agent is demanded, and if the demand is great all the granules may be used up. But as soon as the demand ceases the cells begin again their special vital action and again the granules begin to appear and increase in number until finally the cells become so full that they are fully charged and again ready to pour forth the digestive fluid. This is a daily, almost an hourly process.

Let us take another example in which it would almost appear that there is organic memory on the part of the gland cells. No doubt all have seen the clear jelly-like masses surrounding the eggs of frogs and salamanders. Whence comes this jelly that is so resistent to the agents that work so quickly the destruction of ordinary organic matter? As spring advances the cells of the oviduct increase enormously in size. The microscope shows this increase to be due to a multitude of clear granules. As the eggs move along, the ova are coated with the jelly formed from the granules given out by the cells. As this material for the jelly is poured out the cells gradually shrink to their original size and then wait another twelve months before doing their destined work.

If one can thus catch a glimpse of some of the finer processes taking place in gland action, how is it with nervous action, the highest function of which living matter is capable? While it has been known for a long time that the nervous system is the organ of thought and feeling and the director and co-ordinator of the motions of the body, and many speculations had been made concerning the processes through which the nervous tissue passes 

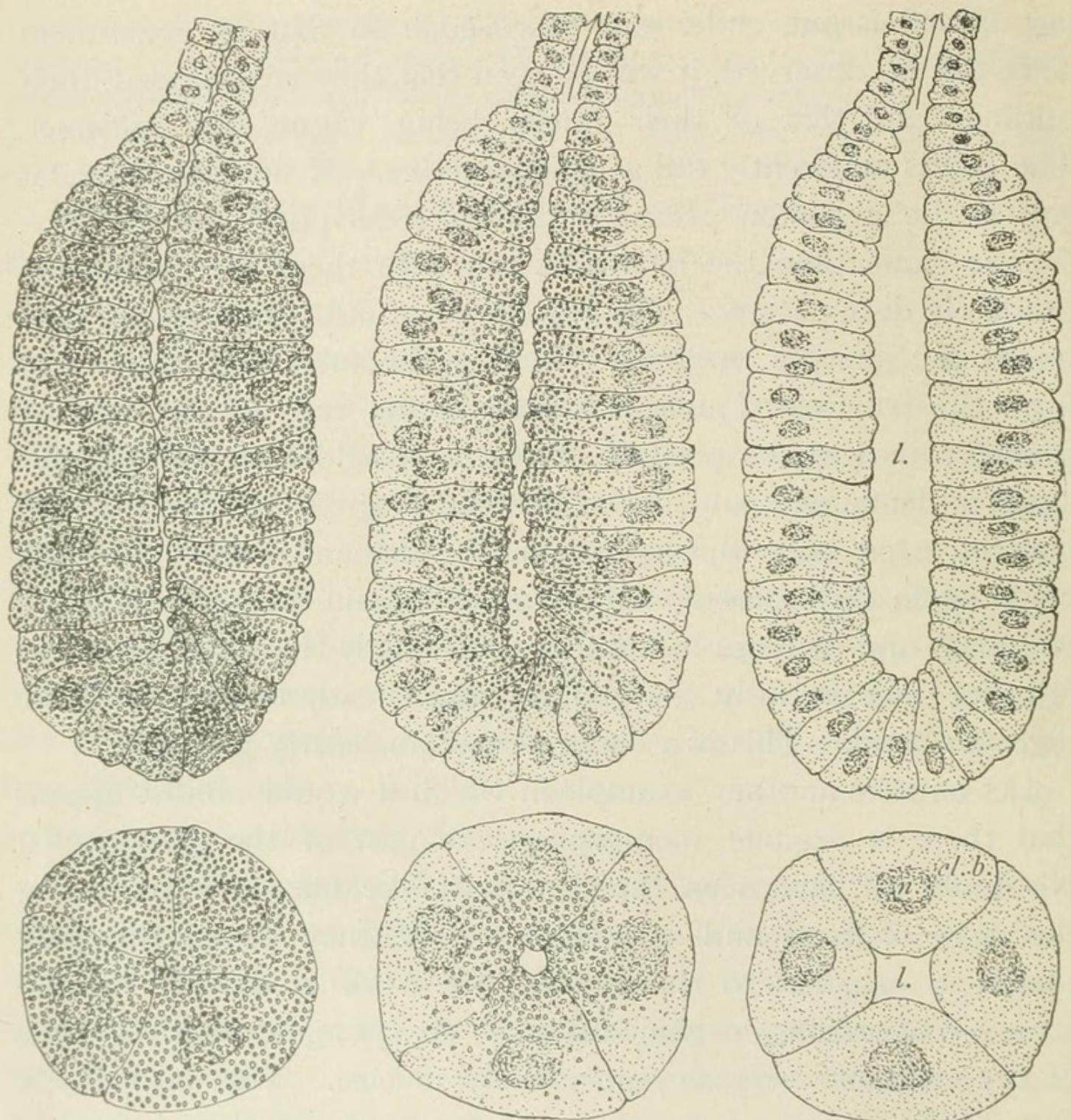

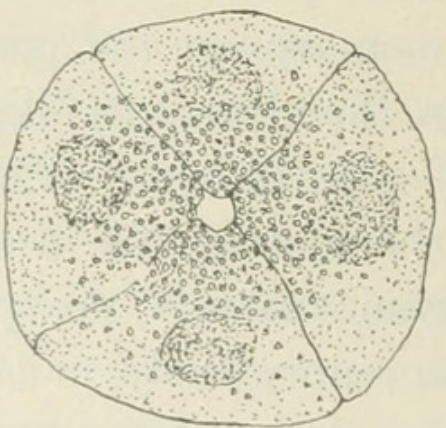

Discharging

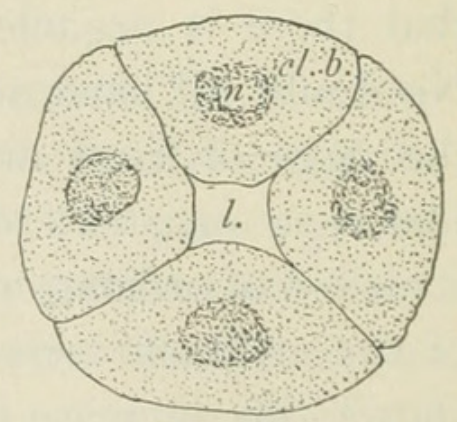

Discharged 89 .

Fig. 3. Sections of a gland in various phases of activity. The upper series represents the gland as in longisection or lengthwise and the lower series in transection or cut across. In the longisections, $(l)$ in the right hand figure represents the cavity or lumen of the gland into which the secretion of the gland is poured. The arrows at the top represent the direction taken by the secretion when it is poured out.

In the lower right hand figure, $(l)$ represents the lumen, $(n)$ the nucleus of one of the cells, and $(\mathrm{cl} . \mathrm{b}$.) the cell body of the same cell. The words Charged, Discharging and Discharged designate the various phases of the gland activity. The process of becoming recharged is not shown.

in performing its functions, it was left to an American student, Dr. Hodge, to first successfully show that there were visible changes through which the nervous system passes in its work. 
The question is, can the activity of the nervous system be traced as surely by changes occurring in the living matter forming its basis, as the action of a gland can be seen by the study of the gland cells?

The demonstration is simple now that the method has been shown. No doubt everyone has had the experience of failing to perform some difficult muscular action at one time and then at another of doing it with ease, or of finding true the reverse of the adage, " practice makes perfect." For example, in a trial of skill, as in learning to ride a bicycle, all the complicated action may be performed with considerable ease and certainty at the beginning of a lesson, when one is fresh, but as the practice continues the results become progressively less and less successful, and finally with increasing weariness there is only failure, and one must rest. We say the muscles are tired; this is true in part, but of much greater importance is the fatigue of the nervous system, as this furnishes the impulses for the action and coordination of the muscles. Now, as muscular action can be seen and the amount can be carefully controlled, here was an exact indicator of the time and amount of the nervous activity. Furthermore, as animals have two similar sides, one arm or leg may work and the other remain at rest, and consequently corresponding sides of the nervous system may be active and at rest. By means of electrical irritation one arm of a cat or other animal was caused to move vigorously for a considerable time, the other arm remaining at rest. Then the two sides of the nervous system, that is, the pairs of nerves to the arms with their ganglia and a segment of the myel (spinal cord) were removed and treated with fixing agents, and carried through all the processes necessary to get thin sections capable of accurate study with the microscope. Finally upon the same glass slide are parts of the nervous system fatigued even to exhaustion, and corresponding parts of the same animal which had been at rest. Certainly if the nervous substance shows the result or processes of its action the conditions are here perfect. Fatigued nerve cells are side by side with those in a state of rest. 
The appearances are clear and unmistakable; the nucleus has markedly decreased in size in the fatigued cells and possesses a jagged, irregular outline in place of the smooth, rounded form of the resting cells. The cell substance is shrunken in size and possesses clear scattered spaces, or a large clear space around the nucleus.

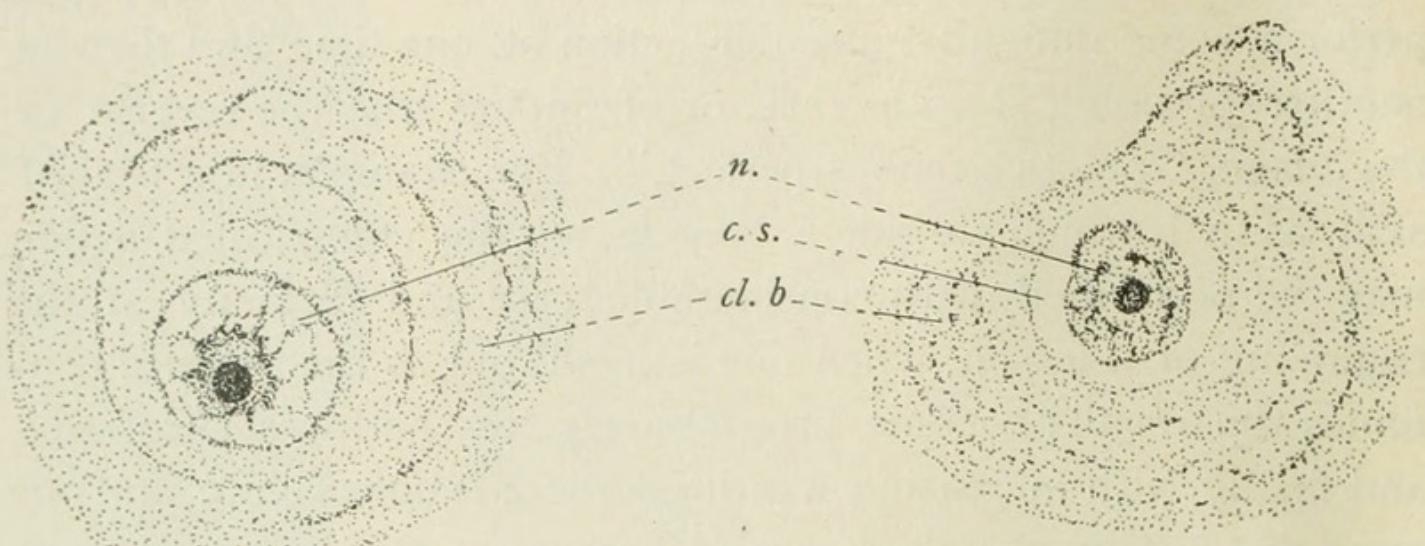

Cat
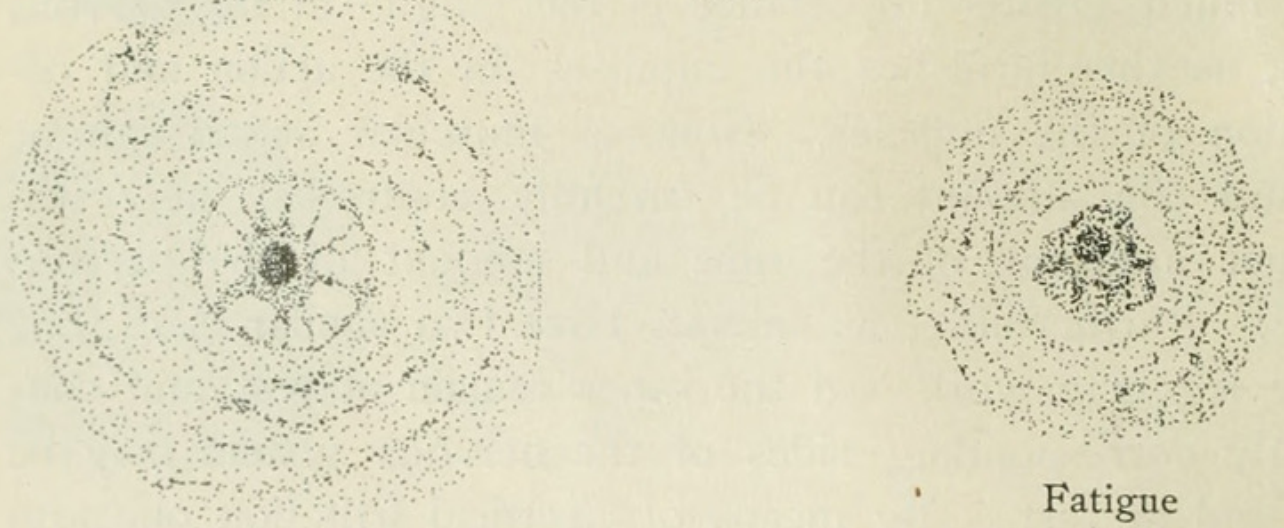

Rest
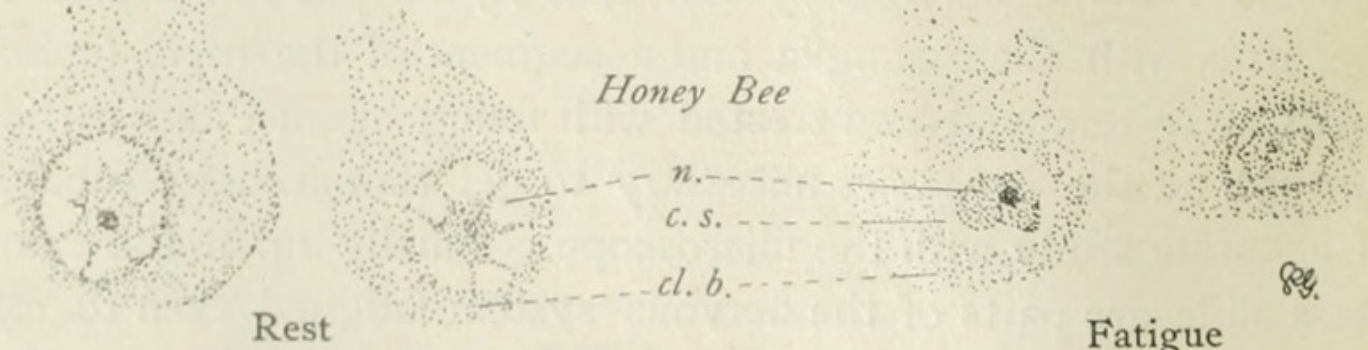

Fatigue

Fig. 4. Figures from Hodge (Jour. Morphology, Vol. VII.), showing changes in the nerve cells of the spinal ganglia, in the cat and of the brain in the honey-bee. The words Rest and Fatigue indicate the appearance of the cells in these two conditions. (n) Nucleus, (cl. b.), cell body, and (c. s.) clear space around the shrunken nucleus in the fatigued cells. 
If the nervous substance was not fixed at once but remained in the living animal for $\mathrm{I} 2$ to 24 hours in a state of repose, the signs of exhaustion disappeared and the two sides appeared alike. By studying preparations made after various periods of repose all the stages of recovery from exhaustion could be followed.

For possible changes in normal fatigue, sparrows, pigeons and swallows and also honey-bees were used. For example, if two sparrows or two honey-bees as nearly alike as possible were selected, the nervous system of one being fixed in the morning after the night's rest and that of the other after a day of toil, the changes in the cells of the brain of the honey-bee or sparrow and in the spinal ganglia of the sparrow were as marked as in case of artificial fatigue. After prolonged rest, then, the nerve cells are, so to speak, charged, they are full and ready for labor, but after a hard day's work they are discharged, shrunken and exhausted.

There is one more step in this brilliant investigation. If in the morning, after sleep and rest, animals and men are full of vigor, and in the evening are weary and exhausted, how like is it to the beginning and end of life? In youth so overflowing with vigor that to move, to act, is pleasure and continued rest a pain ; but in the evening of life a warm corner and repose are what we try to furnish those whose work is done. How is this correlated in the cells of the nervous system with the states of rest and fatigue? With a well-nourished child which died from one of the accidents of birth the nerve cells showed all the characters of cells at rest and fully charged. In a man dying naturally of old age the cells showed the shrunken nuclei and all the appearances of exhausting fatigue. In the one was the potentiality of a life of vigorous action, the other showed, the final fatigue; the store of life energy had been dissipated and there was no recovery possible.

For the animals that possess an undoubted nervous system, probably all would admit that there is some sort of nervous action corresponding to sensation; but what of living matter in the humbler forms where no nervous system can be found? That these have vital motion, that they breathe, nourish themselves, grow and produce offspring none can deny. Do they have anything 
comparable with sensation? As most of the lowest forms are minute, the microscope comes to our aid again, and in watching these lowliest living beings, it is found that they discriminate and choose, going freely into some portions of their liquid world and withdrawing from other portions. If some drug which is unusal or we must believe disagreeable is added to a part of the water, they withdraw from that part. It seems to have the same effect as disagreeable odors on men and animals. On the other hand there are substances which attract and into the water containing these they enter with eagerness. Strange is it, too, that, as proved by experiment, if an unattractive substance is used and also one on the other side that has been found still more unattractive, the less disagreeable is selected, the less of the two evils is chosen.

As man, the horse, dog and many other animals adapt themselves gradually to temperatures either very cold or very warm, and that, too, by a change in their heat-regulating power rather than by a change of hairy or other clothing, so these lowly organisms are found in nature in water at temperatures from near freezing up to 60 or 80 degrees centigrade, a point approaching that of boiling water. It may be answered that each was created for its place, but by means of a microscope and a delicate thermostat, to be certain of every step and to see all the results, Dr. Dallinger, through a period of seven years, accustomed the same unicellular organism and its progeny to variations of temperature from 15 to 20 degrees centigrade, i. e., about the temperature of a comfortable sitting-room, up to $70 \mathrm{C}$. For those at the cooler temperature it was death to increase rapidly the heat Io degrees, and for those at the higher temperature it was equally fatal to lower it to the original temperature of I $_{5}$ to 20 degrees. These examples seem to show that it is one of the fundamental characteristics of living substance, whether in complex or simple forms, to adapt itself to its environment.

There is another fact in nature that the microscope has revealed and that fills the contemplative mind with wonder and an aspiration to see a little farther into the living substance and so per- 
chance discover the hidden springs of action. This fact may be called cellular altriism. In human society the philanthropist and soldier are ready at any time to sacrifice themselves for the race or the nation. With the animals, the guards of the flock or herd are equally ready to die in its defense.

So within each of the higher organisms the microscope has shown a guarding host, the leucocytes or white-blood corpuscles. The brilliant discoveries in the processes. of life with higher forms have shown that not only is there a struggle for existence with dead nature and against forms as large or larger than themselves, but each organism is liable to be undermined by living forms, animal and vegetable, infinitely smaller than themselves, insignificant and insiduous, but deadly. Now to guard the body against these living particles and the particles of dust that would tend to clog the system there is a vast army of amoba-like cells, the leucocytes, that go wherever the body is attacked and do battle. If the guards succeed the organism lives and flourishes, otherwise it dies or becomes weakened and hampered. This much was common scientific property three years ago, when one of our members (Miss Edith J. Claypole) came to my laboratory for advanced work. I discussed with her what has just been given and told her that there still remained to be solved the problem, what becomes of the clogging or deleterious material which the leucocytes have taken up? These body guards are, after all, a part of the organism, and for them simply to engulf the material would not rid the body entirely of it, and finally an inevitable clogging of the system would result. The problem is simple and definite; what becomes of the deleterious substances, bacteria and dust particles that get into the body and become engulfed by the leucocytes? Fortunately, for the solution of this problem, in our beautiful Cayuga Lake, there is an animal, the Necturus, with external gills through which the blood circulates for its purification. So thin and transparent is the covering tissue in these gills that one can see into the blood stream almost as easily as if it were uncovered. Every solid constituent of the blood, whether red corpuscle, white corpuscle, microbe or 
particle of dust, can be seen almost as clearly as if mounted on a microscopic slide.

Into the veins of this animal was injected some lampblack mixed with water, a little gum arabic and ordinary salt, an entirely non-poisonous mixture. Thousands of particles of carbon were thus introduced into the blood and could be seen circulating with it through the transparent gills. True to their duty the white corpuscles in a day or two engulfed the carbon particles, but for several days more the leucocytes could be seen circulating with the blood stream and carrying their load of coal with them. Gradually the carbon-laden corpuscles disappeared and only the ordinary carbon-free ones remained. Where had the carbon been left? Had it been simply deposited somewhere in the system? The tissues were fixed and serial sections made. The natural pigment was bleached with hydrogen dioxid so that if any carbon was present it would show unmistakably. With the exception of the spleen no carbon appeared in the tissues, but in many places the carbon-laden leucocytes were found. In mucous cavities and on mucous surfaces and on the surface of the skin were many of them; in the walls of organs were many more apparently on their way to the surface with their load; that is the carbon is actually carried out of the tissues upon the free surfaces of the skin and mucous membranes where, being outside of the body, it could no more interfere in any way with it. But what is the fate of the leucocytes that carry the lampblack out of the tissues? They carry their load out and free the body, but they themselves perish. They sacrifice themselves for the rest of the body as surely as ever did soldier or philanthropist for the betterment or the preservation of the state.

Thus I have tried to sketch in briefest outline some of the phenomena or processes of life revealed by the microscope. Most of those discussed have come under my own personal observation and are therefore to me particularly real and instructive. But to every one long familiar with the microscope and with the literature of biology many other examples will occur, some of them even more striking. The discussion has been confined to 

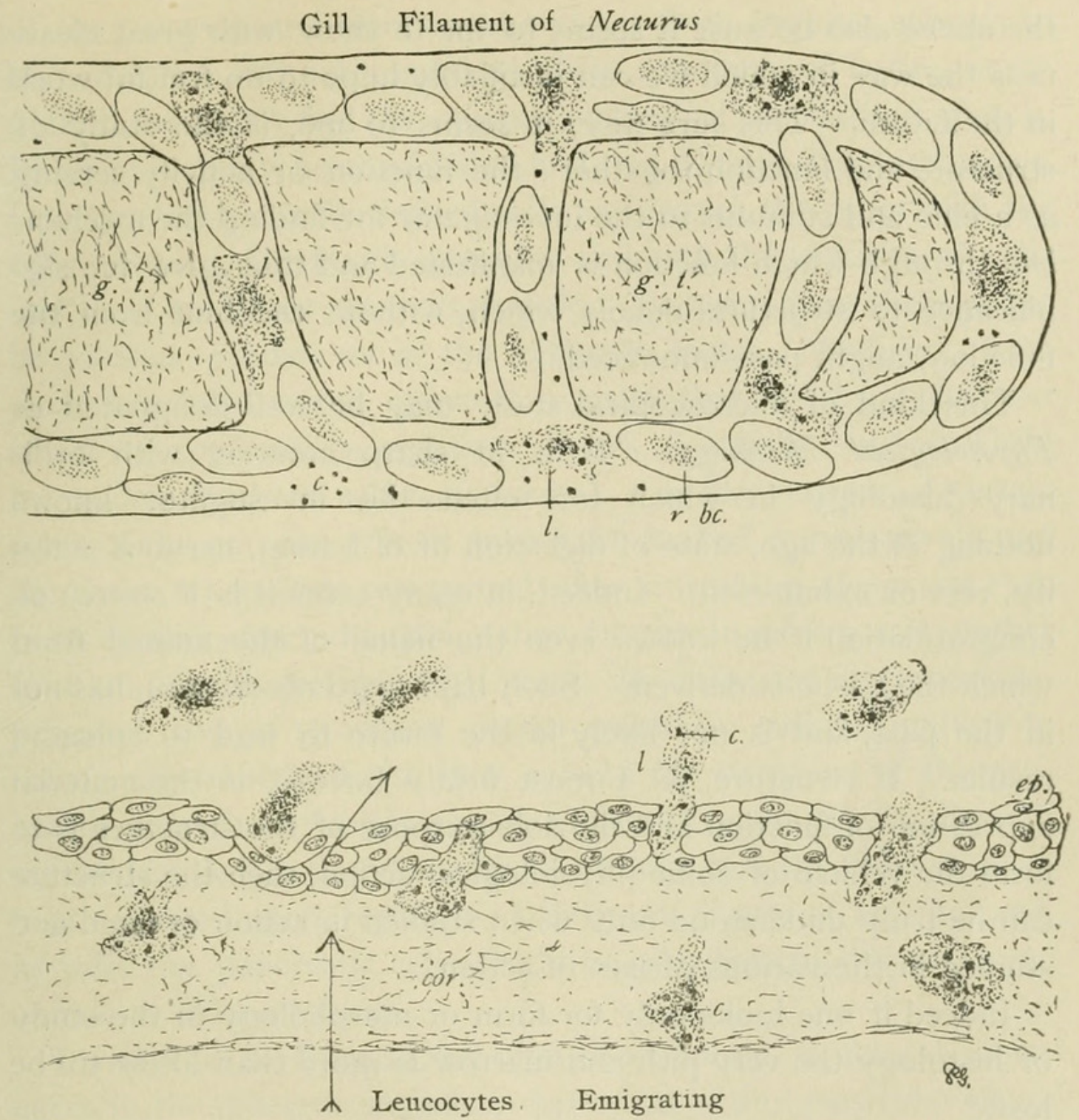

Fig. 5. These figures represent various steps in the removal of foreign matter from the blood of Necturus.

Gill Filament of Necturus. Part of a single gill filament greatly magnified to show the blood vessels containing the red blood corpuscles $(r . b c$.) and the leucocytes $(l$.) or white-blood corpuscles. The black dots $(c$.) within the blood vessels represent carbon particles which had been injected into the veins. In many of the leucocytes are several carbon particles, there are also several shown free in the blood plasma. $(g . t$.) The tissue of the gill filament between the bluod vessels.

Leucocytes Emigrating. This, the lower figure, represents a section of the skin with its covering epithelium (ep.) and the corium (cor.) or true skin. The leucocytes containing carbon particles (c.) are seen in the corium and penetrating the epithelium and finally free outside the epithelium. The arrows indicate that the leucocytes emigrate from the body through the corium and the epithelium, and finally into the space outside the epithelium. 
the above also because it seems to me to show with great clearness the way in which we can justifiably hope to do fruitful work in the future. This sure way, it seems to me, is the study of structure and function together; the function or activity serving as a clue and stimulus to the investigator for finding the mechanism through which function is manifested and thus give due significance to structural details which, without the hint from the function, might pass unnoticed.

This kind of microscopical study may be well designated as Physiological Histology. It is in sharp contrast with ordinary histology in which too often the investigator knows nothing of the age, state of digestion or of fasting, nervous activity, rest or exhaustion. Indeed, in many cases it is a source of congratulation if he knows even the name of the animal from which the tissue is derived. Such haphazard observation has not in the past, and is not likely in the future to lead to splendid results. If structure, as I most firmly believe, is the material expression of function and the sole purpose of the structure is to form the vehicle of some physiological action, then the structure can be truly understood only when studied in action or fixed and studied in the various phases of action.

Indeed if one looks only for form or morphology in the study of histology the very pith and marrow is more than likely to be lost.*

For example, if one wished to study the comparative histology

*Although in a different field, the words of Osborn in discussing the unknown factors of evolution are so pertinent that they may well be quoted: "My last word is, that we are entering the threshold of the Evolution problem, instead of standing within the portals. The hardest task lies before us, not behind us. We are far from finally testing or dismissing these old factors [of evolution], but the reaction from speculation upon them is in itsèlf a silent admission that we must reach out for some unknown quantity. If such does exist there is little hope that we shall discover it except by the most laborious research ; and while we may predict that conclusive evidence of its existence will be found in morphology, it is safe to add that the fortunate discoverer will be a physiologist" [armed with a microscope]. I would like to add the last four words. S. H. G. Am. Nat., May, 1895. 
of the pancreas and were to take pieces from various animals to be compared without regard to their condition of fasting or digestion, he might find the coarser anatomical peculiarities in each. In all probability he would also find two distinct structural types. One type with clearly-defined cells and nuclei, the other with the cells clouded, filled with granules and with the outlines of cells and their nuclei almost indiscernible. Between these there might be various gradations in the different forms. And yet, from what has been stated above it is plain that all these different structural appearances represent phases of activity, and all might have come from the self-same animal. In like manner, if certain parts of the nervous system were to be studied comparatively and the tissue taken from one animal after refreshing sleep and rest, from another after exhausting labor, another in infancy and another from an animal decrepit with years, the difference in general appearance and in structural details would be striking enough to satisfy any morphologist that, as with the structure of the pancreatic cells, there were two or more distinct types; but the physiological histologist would recognize at once that the differences so much insisted upon represented different phases of activity, and, as with the pancreatic cells, might be all represented in the same animal at different times.

I would be far from saying that there are no structural differences in the different animals independent of any particular phase of functional activity; but if these only are sought and the others neglected the physiological appearances will often obtrude and confuse if they do not utterly confound.

I have, therefore, for the last ro years urged my students, and mean to go on advocating with all the earnestness of which I am capable, that in studying an organism or its tissues, the investigator, to gain certain knowledge,must know all that it is possible to learn concerning the age, health, state of nervous, muscular, and digestive activity; in fact, all that it is possible to find out about the processes of life that are going on and have gone on when the study is made.

There are some microscopic forms in which the entire study 
can be made while the creature is alive. With the higher organisms, also, some of the living elements, as the white-blood corpuscles and ciliated cells, can be studied, and their various actions and structural changes observed for a considerable time.

The white-blood corpuscles or leucocytes resemble the amœba very closely in their actions and powers, as we have seen in discussing the way in which the body is freed from foreign particles. The ciliated cells are among the most striking of all the constituent elements of the body. One end is fixed firmly to the tissues, the sides are in contact with their fellow cells, but the other end is free and bears great numbers of hair-like processes, the cilia, which project freely into some cavity or upon some surface. What histologist would be able for a moment to suggest the power of these hair-like processes if he studied the dead cells alone? Yet the moment these cells are studied alive under the microscope it is seen that for the service of the body all the powers of these cells are concentrated into one, that of motion, and all the motion is manifested by the little cilia. These sweep with almost incredible rapidity in one direction and more slowly on their return, thus producing a current in the direction of most rapid motion. This motion with the resulting current ceases only with life. Each individual cilium is weakness itself, but with their combined action the untold millions covering the cells, in the air passages for example, make a strong current in the liquid covering them. This current is from the interior of the lungs toward the throat and carries along with it particles of dust inhaled into the lungs. In this way the delicate breathing organs are swept clean and left unincumbered for their work of receiving oxygen and getting rid of carbon dioxide.

If now one puts under the microscope some cells from the small intestine of almost any animal from the lamprey eel to man, the cells appear almost identical with those just described. The end projecting to the free surface of the intestine seems to have a similar brush of fine hairs, with a clear line along their base. If a striated and a dead ciliated cell are under the same microscope side by side it is almost impossible to distinguish them. Indeed 

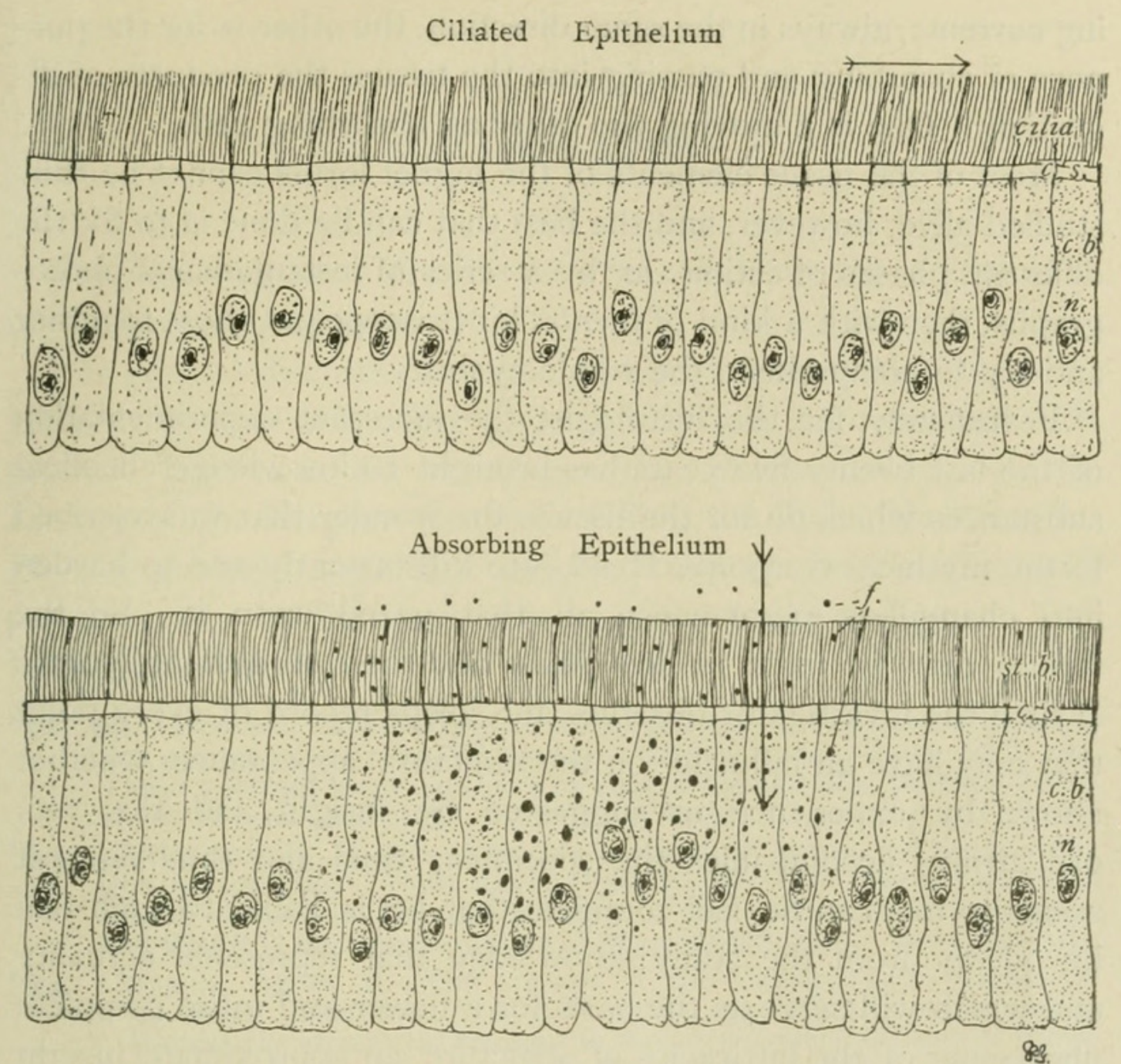

Fig. 6. Figures showing the similarity in appearance of the absorbing epithelium of the intestine and of a ciliated epithelium. The free ends of the cells point upward toward the top of the page and the attached ends toward the bottom of the page. (cilia). The minute hair-like processes projecting from the free end of the cells and constantly swinging rapidly in one direction and returning less rapidly to the starting point. In this way a current is made in the direction of the most rapid motion (indicated by the arrow). At the base of the cilia is a clear plate or segment (c. s.)

In the absorbing epithelium the segment appearing like the cilia is called the striated border or segment (st. b.) and rests on a clear segment (c. s.) comparable with that on which the cilia rest. In the absorbing epithelium food particles $(f$.) are represented as passing through the cell from the free end toward the base, as indicated by the arrow.

so difficult is it that those from the intestine have been described as ciliated more than once. If both cells are living no one could confuse them. The striated end of one is motionless, the lines or cilia of the other are in constant motion. One serves for produc- 
ing currents, always in the same direction, the other is for the purpose of absorbing and passing into the tissues the products of digestion. One is a moving the other an absorbing cell.

Most of the tissue elements of the higher forms cannot be thus studied alive, however, and the best that can be done is to fix the different phases of action, as by a series of instantaneous photographs, then with a kind of mental kinetoscope put these together and try to comprehend the whole cycle.

Fortunately for the histologist the incessant experimentation of the last twenty-five years has brought to knowledge chemical substances which do for the tissues the wonder that was ascribed to the mythical Gorgon's Head,- - to kill instantly and to harden into changeless permanence all that gazed upon it. So the tissues may be fixed in any phase and then studied at length. If then the investigator observes and keeps record of every point that may have an influence on the structural appearances, whether shown by experience or suggested by insight, and this record always accompanies the specimen, thus and thus only, it seems to me, can he feel confident that he is liable to gain real knowledge from the study, knowledge that represents actuality and which will serve as the basis for a newer and more complete unraveling of the intricacies of structure, an approximate insight into the mechanism through which the life energy manifests itself.

And so, with all the light that physics and chemistry can give, commencing with the simplest problems and being careful that every factor that can influence the result is being duly considered, the microscopist can go forwald with enthusiasm and with hope, not with the hope that the great central question can be answered in one generation, perhaps not in a thousand, but confident that if each one adds his little to the certain knowledge of the world, then in the fullness of time the knowledge of living substance and the life processes will be so full and deep that what Life Is, though unanswered, may cease to be the supreme question. 


\section{BIBLIOGRAPHY.}

The following are a few of the works used in the preparation of the foregoing address :

For general discussions of the problems treated, the works of Herbert Spencer and other philosophers may be consulted with profit. For extended references, the Index Catalog of the Library of the Surgeon General's Office, the Index Medicus, the Physiologisches Centralblatt and the Anatomischer Anzeiger wil put the reader on the track of most of the books and papers that have appeared.

'78-'79. Bernard, Claude-Leçons sur les phénomènes de la vie commune aux animaux et aux végétaux. T'wo volumes, Paris, (1878-79). These volumes show, in the way only a master like Bernard could show, the essential unity of the life processes in animals and plants.

95. Chittenden, R. H.-On digestive proteolysis, being the Cartwright lectures for 1894. New Haven, 1895, p. 137. He makes very clear that in absorption the vital activity of the epithelium is necessary, and that it is not a mere matter of physical diffusion. See p. 116, ete.

94. Claypole, Agnes M.-The enteron of the Cayuga Lake Lamprey. Proc. Amer. Micr. Soc., Vol. XVI. (1894), pp. 125-164, eight plates.

Besides the structural changes in the physiological process of transformation from the larval to the adult condition, the enteric epithelium and its structural features in action are shown; also the ciliated and striated border of the enteric epithelial cells.

93. Claypole, Edith J.-An investigation of the blood of Necturus and Cryptobranchus. Proc. Amer. Micr. Soc., Vol. XV. (1893), pp. 39-76, six plates. This is the investigation referred to in discussing cellular altruism, p. 17 of the address.

94. Cope, E. D.-The Energy of Evolution. American Naturalist, Vol. XXVIII. (1894), pp. 205-219. From this paper is taken the quotation on p. 5 of the address.

'80. Dallinger, W. H.-On a series of experiments made to determine the thermal doth-point of known monad germs when the heat is endured in a fluid. Journal of the Royal Microscopical Society, Vol. III. (1880), pp. 1-16. See also his Presidential Address published in the same Journal, pp. 185-199 (1887).

This investigation was carried on for nearly seven years, and organisms living normally. at a temperature of $15^{\circ}$ to $20^{\circ}$ centigrade were enured to a temperature of $70^{\circ} \mathrm{C}$. Dr. Dallinger pointed out some of the physical appearances passed through by the organisms in their acclimatization. See also Davenport and Castle.

See p. 16 of the address. 
95. Davenport, C. B. and Castle, W. E.-On the acclimatization of organisms to high temperatures. Archiv für Entwickelungsmechanik der Organismen. II. Band, 2 Heft. pp. 227-249. This paper gives in tabular form a history of the observations of various authors on acclimatization of various living forms naturally, as in the waters of hot springs, and artificially. Their own experiments on tad-poles are highly suggestive and they point out some of the chemicophysical changes occurring in the adaptation of the living substance to the unusual environments. See also Dallinger.

95 Foster, M.-Text book of physiology. (New York and London, 1895). In this work there is stated very clearly what is known and what is not known concerning the processes of life.

'85. Gage, Simon H.-The limitations and value of histological investigation. Proceedings Amer. Assoc. Adv. Sci., Vol. XXXIV. (1885), pp. 345-349. In this paper is pointed out the necessity of studying function as well as structure in histological investigations if any thing like a complete understanding of a tissue or organ is obtained.

'93. Gould, George M.-The meaning and method of life. 297 pages, New York (1893). This is a most stimulating and inspiring work. The quotation on p. 5 of the address is from it.

95. Hertwig, Oscar. - The cell, outlines of general anatomy and physiology, translated by M. and edited by H. J. Campbell. P. 368, 168 illustrations. (London and New York, 1895) Dr. Hertwig lays special stress on the function of the structural elements.

'92. Hodge, C. F.-A microscopical study of changes due to functional activity in nerve cells. Journal of Morphology, Vol. VII. (1892), pp. 95-168. Two plates. In this paper and the next are given the facts on which the statements concerning the changes in nerve cells mentioned in this address are based. There is also in this an excellent resumé of what is known of structural appearances due to vital activity in gland cells.

'95. Hodge, C. F.-Changes in ganglion cells from birth to senile death. Observations on man and the honey bee. Journal of Physiology, Vol. XVII., pp. 129-134, one plate.

'88. Howell, W. H.-The Physiology of Secretion. The Reference HandBook of the Medical Sciences, (N. Y., 1888), pp. 363-379.

In this article Dr. Howell gives a very admirable account of secretion; and bearing upon the dissimilarity of living and lifeless things says that something more than simple physical law is necessary to explain the differences.

'94. Kingsbury, B. F.-The histological structure of the enteron of 1 Necturus maculatus. Proceedings of the American Microscopical Society, Vol. XVI. (1894), pp. 21-64, eight plates.

In this pap r the structural appearances accompanying activity in the enteric epithelium are described and figured.

'8 r. Langley, J. N.-On the histology and physiology of the pepsin forming glands. Philos. Trans., pp. 663-711 (1881).

'93. Metchnikoff, Elias.-Lectures on the comparative pathology of inflammation delivered at the Pasteur Institute in 1891. Translated from the French by F. A. and E. H. Starling. P. 218; three colored plates and 65 figures in the text. (London, 1893).

'My principal object in writing this book is to show the intimate connection that exists between pathology and biology properly so called." Author's preface. For the purposes of the preceding address 
the parts of the book showing the activities of unicellular organisms, their attraction and repulsion by various agents and the action of the leucocytes in ridding the body of hurtful or clogging matter are of especial importance.

95. Sedgwick, Wm. T. and Wilson E. B.-An introduction to general biology, p. 231, 105 Figs. 2d edition (N. Y., 1895.)

This work emphasizes the physiological side of the organism, and the first chapters discuss with clearnesss and force the characters of living things.

92. Thomson, Sir Wm. (Lord Kelvin).-On the dissipation of energy. Fortnightly Review, Vol. 57 (1892), pp. 313 to 321. In this paper may be found the quotation given on p. 4 of the address and also the statement of Liebig. For this see the foot note to the article of Thomson, p. 317.

'85. Tait, P. G.-Properties of matter with an appendix on hypotheses as to the constitution of matter by Prof. Flint, D. D. (Edinburgh, 1885). P. p. 320 ,

'94-'95. Thurston, R. H.-The animal as a machine and a prime motor. (N. Y., 1894).

See also Science, April 5, '95, and Journal of the Franklin Institute, January-March, '95. It is shown that the animal machine is the most efficient of all known machines, and the sentiment is expressed that a comprehension of the processes of life is of as much interest to the engineer as to the physiologist.

95. Whitman, C. O.-Evolution and epigenesis. In Biological lectures delivered at the Marine Biological Laboratory at Wood's Holl, in 1894. In the prefatory note is given a discussion relating to matter and energy.

See also his articles in the Journal of Morphology, Vol. I., pp. 227-252; Vol. II., pp. 27-49; Vol. VIII., pp. 639-658. 


\section{$2 \mathrm{BHL}$ Biodiversity Heritage Library}

Gage, Simon Henry. 1896. "Address of the President: The Processes of Life Revealed by the Microscope; A Plea for Physiological Histology." Transactions 17, 3-29.

View This Item Online: https://www.biodiversitylibrary.org/item/86837

Permalink: https://www.biodiversitylibrary.org/partpdf/90817

\section{Holding Institution}

University of Toronto - Gerstein Science Information Centre

\section{Sponsored by}

University of Toronto

\section{Copyright \& Reuse}

Copyright Status: Not provided. Contact Holding Institution to verify copyright status.

This document was created from content at the Biodiversity Heritage Library, the world's largest open access digital library for biodiversity literature and archives. Visit BHL at https://www.biodiversitylibrary.org. 